\title{
FAKTOR-FAKTOR YANG MEMPENGARUHI KINERJA KARYAWAN LION GROUP PERWAKILAN KALIMANTAN
}

\begin{abstract}
Dinan
Email : dinan@gmail.com

STIE Palangka Raya

ABSTRACT

The research aims to examine and analyze the influence of leadership style, motivation and work discipline toward performance of employee in Lion Group Distric Kalimantan. Data collected through distribution of questionnaires and it is implemented to Lion Group Distric Kalimantan 112 employee. Analysis of data in this research using the help of SPSS version 27. A sampling technique uses a census method and data test technique is used within the research includes validity test by factor analysis, reliability test with cronbach. Classic assumption test and double linear regression analysis, to verify and to prove the research hypothesis.

Analysis result demonstrates that leadership style have a positive influence toward employee performance. Motivation have a positive influence toward employee performance and work discipline have a positive influence toward employee performance.
\end{abstract}

Keywords : Leadership style, Motivation, work Discipline and performance. 


\section{PENDAHULUAN}

Pengorganisasi faktor manusia merupakan masalah utama disetiap kegiatan untuk pencapaian tujuan organisasi. Organisasi merupakan kesatuan sosial yang dikoordinasikan secara sadar dengan sebuah batasan yang reaktif dapat diidentifikasikan, bekerja secara terus menerus untuk mencapai tujuan (Robbins, 2006).

Sumber daya manusia merupakan tokoh sentral dalam organisasi maupun perusahaan. Agar aktivitas manajemen berjalan dengan baik, perusahaan harus memiliki karyawan yang berpengetahuan dan berketrampilan tinggi serta usaha untuk mengelola perusahaan seoptimal mungkin sehingga kinerja karyawan meningkat.

Menurut Budi Setiyawan dan Waridin (2006) kinerja karyawan merupakan hasil atau prestasi kerja karyawan yang dinilai dari segi kualitas maupun kuantitas berdasarkan standar kerja yang ditentukan oleh pihak organisasi. Kinerja yang baik adalah kinerja yang optimal, yaitu kinerja yang sesuai standar organisasi dan mendukung tercapainya tujuan organisasi. Organisasi yang baik adalah organisasi yang berusaha meningkatkan kemampuan sumber daya manusianya, karena hal tersebut merupakan faktor kunci untuk meningkatkan kinerja karyawan.

Kinerja karyawan yang tinggi sangatlah diharapkan oleh perusahaan terserbut. Semakin banyak karyawan yang mempunyai kinerja tinggi, maka produktivitas perusahaan secara keseluruhan akan meningkat sehingga perusahaan akan dapat bertahan dalam persaingan global. Karyawan dituntut untuk mampu menyelesaikan tugas dan tanggung jawabnya secara efektif dan efisien. Keberhasilan karyawan dapat diukur melalui kepuasan konsumen, berkurangnya jumlah keluhan dan Jurnal Komunikasi Bisnis dan Manajemen

Vol.5 No.2 Juli 2018 
tercapainya target yang optimal.

Faktor-faktor yang dapat digunakan untuk meningkatkan kinerja diantaranya adalah gaya kepemimpinan, motivasi dan disiplin kerja. Gaya kepemimpinan merupakan norma perilaku yang digunakan oleh seseorang pada saat orang tersebut mencoba mempengaruhi perilaku orang lain (Suranta, 2002). Gaya kepemimpinan cocok apabila tujuan perusahaan telah dikomunikasikan dan bawahan telah menerimanya. Seorang pemimpin harus menerapkan gaya kepemimpinan untuk mengelola bawahannya, karena seorang pemimpin akan sangat mempengaruhi keberhasilan organisasi dalam mencapai tujuannya (Waridin dan Bambang Guritno, 2005).

Perusahaan menggunakan penghargaan atau hadiah dan ketertiban sebagai alat untuk memotivasi karyawan. Pemimpin mendengar ide-ide dari para bawahan sebelum mengambil keputusan. Gaya kepemimpinan yang tepat akan menimbulkan motivasi seseorang untuk berprestasi. Sukses tidaknya karyawan dalam prestasi kerja dapat dipengaruhi oleh gaya kepemimpinan atasannya (Hardini, 2001 dalam Suranta, 2002). Suranta (2002) dan Tampubolon (2007) telah meneliti pengaruh gaya kepemimpinan terhadap kinerja, menyatakanbahwa gaya kepemimpinan mempunyai pengaruh yang signifikan terhadap kinerja karyawan.

Motivasi adalah dorongan, upaya dan keinginan yang ada di dalam diri manusia yang mengaktifkan, memberi daya serta mengarahkan perilaku untuk melaksanakan tugas-tugas dengan baik dalam lingkup pekerjaannya (Hakim, 2006). Robbins (2006) mendefinisikan motifasi sebagai proses yang ikut menentukan intensitas, arah, dan ketekunan individu dalam usaha mencapai sasaran.

Menurut Budi Setiyawan dan Waridin (2006) disiplin sebagai Jurnal Komunikasi Bisnis dan Manajemen Vol.5 No.2 Juli 2018 
keadaan ideal dalam mendukung pelaksanaan tugas sesuai aturan dalam rangka mendukung optimalisasi kerja. Salah satu syarat agar disiplin dapat ditumbuhkan dalam lingkungan kerja ialah, adanya pembagian kerja yang tuntas sampai kepada pegawai atau petugas yang paling bawah, sehingga setiap orang tahu dengan sadar apa tugasnya, bagaimana melakukannya, kapan pekerjaan dimulai dan selesai, seperti apa hasil kerja yang disyaratkan, dan kepada siapa mempertanggung jawabkan hasil pekerjaan itu (Budi Setiyawan dan Waridin, 2006).

Disiplin harus ditumbuh kembangkan agar tumbuh pula ketertiban dan evisiensi. Tanpa adanya disiplin yang baik, jangan harap akan dapat diwujudkan adanya sosok pemimpin atau karyawan ideal sebagaimana yang diharapkan oleh masyarakat dan perusahaan.

Menurut Budi Setiyawan dan Waridin (2006), dan Aritonang (2005) disiplin kerja karyawan bagian dari faktor kinerja. Hasil penelitiannya menunjukan bahwa disiplin kerja memiliki pengaruh positif terhadap kinerja kerja karyawan.

Penelitian ini dilakukan dengan tujuan untuk mengetahui (1) Pengaruh variabel gaya kepemimpinan terhadap kinerja karyawan (2) Pengaruh variabel motivasi terhadap kinerja karyawan (3) Mengetahui pengaruh variabel disiplin kerja terhadap kinerja karyawan.

\section{TINJAUAN PUSTAKA}

\section{Kinerja karyawan}

Kinerja sebagai hasil-hasil fungsi pekerjaan/kegiatan seseorang atau kelompok dalam suatu organisasi yang dipengaruhi oleh berbagai faktor untuk mencapai tujuan organisasi dalam periode waktu tertentu (Tika, 2006). Sedangkan menurut Rivai dan Basri (2005) kinerja adalah kesediaan seseorang atau kelompok orang untuk melakukan sesuatu kegiatan dan Jurnal Komunikasi Bisnis dan Manajemen Vol.5 No.2 Juli 2018 
menyempurnakannya sesuai dengan tanggung jawab dengan hasil seperti yang diharapkan.

Menurut Bambang Guritno dan Waridin (2005) kinerja merupakan perbandingan hasil kerja yang dicapai oleh karyawan dengan standar yang telah ditentukan. Sedangkan menurut Hakim (2006) mendefinisikan kinerja sebagai hasil kerja yang dicapai oleh individu yang disesuaikan dengan peran atau tugas individu tersebut dalam suatu perusahaan pada suatu periode waktu tertentu, yang dihubungkan dengan suatu ukuran nilai atau standar tertentu dari perusahaan dimana individu tersebut bekerja. Kinerja merupakan perbandingan hasil kerja yang dicapai oleh pegawai dengan standar yang telah ditentukan (Masrukhin dan Waridin, 2004).

Berdasarkan pengertian kinerja dari beberapa pendapat diatas, kinerja merupakan perbandingan hasil kerja yang dicapai oleh karyawan dengan standar yang telah ditentukan. Kinerja juga berarti hasil yang dicapai oleh seseorang, baik kuantitas maupun kualitas dalam suatu organisasi sesuai dengan tanggung jawab yang dberikan kepadanya.

\section{Gaya Kepemimpinan}

Gaya kepemimpinan adalah bagaimana seorang pemimpin melaksanakan fungsi kepemimpinan dan bagaimana dilihat oleh mereka yang berusaha dipimpinnya atau mereka yang mungkin sedang mengamati dari luar (Robert, 1992).

James (1996) mengatakan bahwa gaya kepemimpinan adalah berbagai pola tingkah laku yang disukai oleh pemimpin dalam proses mengarahkan dan mempengaruhi pekerja. Gaya kepemimpinan adalah perilaku dan strategi, sebagai hasil kombinasi dari falsafah, ketrampilan, sifat, sikap, yang sering diterapkan seorang pemimpin ketika ia mencoba mempengaruhi kinerja bawahannya (Tampubolon, 2007).

Jurnal Komunikasi Bisnis dan Manajemen

Vol.5 No.2 Juli 2018 
Berdasarkan definisi gaya kepemimpinan diatas dapat disimpulkan bahwa kepemimpinan adalah kemampuan seseorang dalam mengarahkan, mempengaruhi, mendorong dan mengendalikan orang lain atau bawahan untuk bisa melakukan sesuatu pekerjaan atas kesadarannya dan sukarela dalam mencapai suatu tujuan tertentu. Kepemimpinan memegang peran yang signifikan terhadap kesuksesan dan kegagalan sebuah organisasi.

\section{Motivasi}

Menurut Malthis (2001) motivasi merupakan hasrat didalam diri seseorang yang menyebabkan orang tersebut melakukan tindakan. Sedangkan Rivai (2004) berpendapat bahwa motivasi adalah serangkaian sikap dan nilai-nilai yang mempengaruhi individu untuk mencapai hal yang spesifik sesuai dengan tujuan individu.

Motivasi adalah kesediaan melakukan usaha tingkat tinggi guna mencapai sasaran organisasi yang dikondisikan oleh kemampuan usaha tersebut memuaskan kebutuhan sejumlah individu (Robins dan Mary, 2005).

Motivasi merupakan faktor psikologis yang menunjukan minat individu terhadap pekerjaan, rasa puas dan ikut bertanggung jawab terhadap aktivitas atau pekerjaan yang dilakukan (Masrukhin dan Waridin, 2004). Sedangkan Hasibuan (2004) berpendapat bahwa motivasi adalah hal yang menyebabkan, menyalurkan dan mendukung perilaku manusia, supaya mau bekerja giat dan antusias mencapai hasil yang optimal. Motivasi merupakan sesuatu yang membuat bertindak atau berperilaku dalam cara-cara tertentu (Armstrong, 1994).

Berdasarkan pengertian diatas disimpulkan bahwa motivasi merupakan kegiatan yang mengakibatkan, menyalurkan, memelihara dan mendorong perilaku manusia. Pemimpin perlu memahami orang-orang berperilaku tertentu agar dapat mempengaruhinya dalam bekerja sesuai Jurnal Komunikasi Bisnis dan Manajemen Vol.5 No.2 Juli 2018 
dengan keinginan organisasi.

Siagian (2002) mengemukakan bahwa dalam kehidupan berorganisasi, termasuk kehidupan berkarya dalam organisasi bisnis, aspek motivasi kerja mutlak mendapat perhatian serius dari para manajer.

\section{Disiplin Kerja}

Menurut Simamora (1997) disiplin adalah prosedur yang mengoreksi atau menghukum bawahan karena melanggar peraturan atau prosedur. Disiplin kerja adalah suatu alat yang digunakan para manajer untuk berkomunikasi dengan karyawan agar mereka bersedia untuk mengubah suatu perilaku serta sebagai suatu upaya untuk meningkatkan kesadaran dan kesediaan seseorang menaati semua peraturan perusahaan dan normanorma sosial yang berlaku (Rivai, 2004).

Hasibuan (2004) berpendapat bahwa kedisiplinan adalah kesadaran dan kesediaan seseorang menaati semua peraturan perusahaan dan norma-norma sosial yang berlaku. Berdasarkan pengertian diatas disimpulkan bahwa disiplin kerja merupakan suatu sikap, tingkah laku, dan perbuatan yang sesuai dengan peraturan baik tertulis maupun tidak tertulis, dan bila melanggar akan ada sanksi atas pelanggarannya.

\section{Kerangka Pemikiran}

Uraian pemikiran tersebut diatas dapat diperjelas melalui variabel pengaruh gaya kepemimpinan, motivasi dan disiplin kerja terhadap kinerja karyawan, secara skematis digambarkan seperti pada gambar dibawah ini : 


\section{Gambar 1}

Kerangka Pemikiran Peneliti

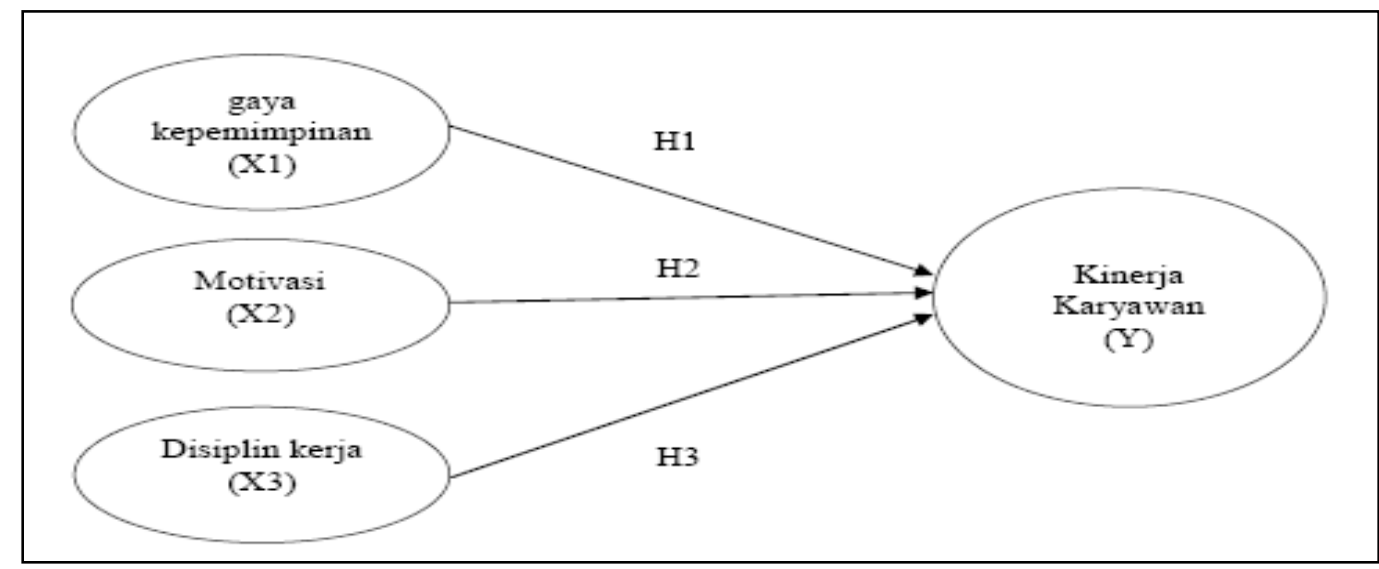

Sumber: Kerangka Pikir yang dikembangkan dalam penelitian ini (2017)

\section{METODE PENELITIAN}

\section{Variabel Penelitian}

Variabel penelitian adalah hal-hal yang dapat membedakan atau membawa variasi pada nilai (Sekaran, 2006). Penelitian ini menggunakan dua variabel yaitu variabel independen dan variabel dependen adalah merupakan variabel yang menjadi pusat perhatian peneliti.

Hakekat sebuah masalah, mudah terlihat dengan mengenali berbagai variabel dependen yang digunakan dalam sebuah model (Ferdinand, 2006). Dalam penelitian ini yang menjadi variabel terikat adalah kinerja karyawan (Y). (b) Variabel bebas (Independent Variable) yaitu Variabel independen adalah variabel yang mempengaruhi variabel dependen, baik yang pengaruhnya positif maupun yang pengaruhnya negatif (Ferdinand, 2006). Variabel bebas dalam penelitian ini adalah (a) Gaya kepemimpinan (X1), (b) Motivasi (X2) dan (c) Disiplin kerja (X3).

\section{Penentuan Populasi dan Sampel}

Populasi adalah gabungan dari seluruh elemen yang berbentuk peristiwa, hal, atau orang yang memiliki karakteristik serupa yang menjadi 
pusat perhatian peneliti, karenanya dipandang sebagai semesta penelitian (Ferdianad, 2006). Poulasi dalam penelitian ini adalah seluruh karyawan yang ada di perusahaan Lion Group Perwakilan Kalimantan yang berjumlah 112 karyawan.

\section{Jenis dan Sumber Data}

Data adalah segala sesuatu yang diketahui atau dianggap mempunyai sifat bisa memberikan gambaran tentang suatu keadaan atau persoalan (Supranto, 2001). Data yang digunakan dalam penelitian ini meliputi (a) Data Primer, Menurut Algifari (1997), data primer merupakan data yang diperoleh secara langsung dari sumber asli (tanpa melalui perantara). Data primer yang ada dalam penelitian ini merupakan data kuesioner (b) Data Sekunder adalah data penelitian yang diperoleh secara tidak langsung melalui media perantara (diperoleh dan dicatat oleh pihak lain).

\section{Metode Pengumpulan Data}

Metode pengumpulan data yang digunakan dalam penelitian ini adalah (a) Kuesioner, Metode Kuesioner adalah metode pengumpulan data yang dilakukan dengan cara memberikan pertanyaan-pertanyaan kepada responden dengan panduan kuesioner. Kuesioner dalam penelitian ini menggunakan pertanyaan terbuka dan tertutup (b) Observasi, Metode observasi merupakan metode penelitian dimana Peneliti melakukan pengamatan secara langsung pada obyek penelitian (c) Studi Pustaka, Metode Studi pustaka merupakan metode pengumpulan data yang dilakukan dengan membaca buku-buku, literatur, jurnal-jurnal, referensi yang berkaitan dengan penelitian ini dan penelitian terdahulu yang berkaitan dengan penelitian yang sedang dilakukan.

\section{Metode Analisis Data}

Sebelum melakukan analisis data, maka perlu dilakukan tahapJurnal Komunikasi Bisnis dan Manajemen Vol.5 No.2 Juli 2018 
tahap teknik pengolahan data sebagai berikut (a) Editing, Metode Editing merupakan proses pengecekan dan penyesuain yang diperoleh terhadap data penelitian untuk memudahakan proses pemberian kode dan pemrosesan data dengan teknik statistik (b) Coding, Metode Coding merupakan kegiatan pemberian tanda berupa angka pada jawaban dari kuesioner untuk kemudian dikelompokkan ke dalam kategori yang sama. Tujuannya adalah menyederhanakan jawaban (c) Scoring, (d) Tabulating, Metode Tabulating yaitu menyajikan data-data yang diperoleh dalam tabel, sehingga diharapkan pembaca dapat melihat hasil penelitian dengan jelas. Setelah proses tabulating selesai dilakukan, diolah dengan program komputer SPSS 27. Analisis pengaruh menggunakan Regresi Linear Berganda, digunakan untuk mengetahui seberapa besar pengaruh variabel bebas yaitu: gaya kepemimpinan (X1), motivasi (X2), dan disiplin kerja (X3) terhadap variabel terikatnya yaitu kinerja karyawan (Y). Persamaan regresi linier berganda adalah sebagai berikut (Ghozali, 2005):

$$
Y=a+b 1 X 1+b 2 X 2+b 3 X 3+e
$$

Dimana :

$$
\begin{aligned}
& \mathrm{Y}=\text { Variabel dependen (kinerja karyawan) } \\
& \text { a } \quad=\text { Konstanta } \\
& \mathrm{b} 1, \mathrm{~b} 2, \mathrm{~b} 3=\text { Koefisien garis regresi } \\
& \mathrm{X} 1, \mathrm{X} 2, \mathrm{X} 3=\text { Variabel independen (gaya kepemimpinan, motivasi, } \\
& \text { disiplin kerja) } \\
& \text { e } \quad=\text { error } / \text { variabel pengganggu }
\end{aligned}
$$

\section{HASIL PENELITIAN}

\section{Analisis Persamaan Regresi Linear Berganda}

Analisis regresi digunakan untuk menguji hipotesis tentang pengaruh secara parsial variabel bebas terhadap variabel terikat. Berdasarkan estimasi regresi berganda dengan program SPSS 27 diperoleh hasil seperti tabel 1. 
Tabel 1

Hasil Estimasi Regresi

\section{Coefficients $^{\mathrm{a}}$}

\begin{tabular}{|c|c|c|c|c|c|c|c|}
\hline \multirow[b]{2}{*}{ Model } & \multicolumn{2}{|c|}{$\begin{array}{c}\text { Unstandardized } \\
\text { Coefficients }\end{array}$} & \multirow{2}{*}{$\begin{array}{c}\text { Standardized } \\
\text { Coefficients } \\
\text { Beta }\end{array}$} & \multirow[b]{2}{*}{$\mathrm{T}$} & \multirow[b]{2}{*}{ Sig. } & \multicolumn{2}{|c|}{$\begin{array}{c}\text { Collinearity } \\
\text { Statistics }\end{array}$} \\
\hline & $\mathrm{B}$ & Std. Error & & & & Tolerance & VIF \\
\hline 1 (Constant) & 2.787 & 1.522 & & 1.831 & .070 & & \\
\hline $\begin{array}{c}\text { Gaya } \\
\text { Kepemimpinan }\end{array}$ & .460 & .122 & .316 & 3.784 & .000 & .555 & 1.801 \\
\hline Motivasi & .329 & .091 & .343 & 3.628 & .000 & .434 & 2.305 \\
\hline Disiplin Kerja & .259 & .097 & .222 & 2.665 & .009 & .556 & 1.799 \\
\hline
\end{tabular}

a. Dependent Variable: Kinerja Karyawan

Sumber : output SPSS diolah, 2017

Berdasarkan tabel 1 dapat diketahui persamaan regresi yang terbentuk adalah :

$$
Y=0,316 X 1+0,343 X 2+0,222 X 3
$$

Keterangan :

$\mathrm{Y}=$ Kinerja karyawan

$\mathrm{X} 1$ = Gaya Kepemimpinan

X2 = Motivasi

X3 = Disiplin kerja

\section{Pengujian Hipotesis}

\subsection{Uji F ( Pengujian hipotesis secara simultan)}

Untuk menguji pengaruh variabel bebas secara bersama-sama diuji dengan menggunakan uji F. Hasil perhitungan regresi secara simultan diperoleh sebaga berikut :

Tabel 2

Jurnal Komunikasi Bisnis dan Manajemen

Vol.5 No.2 Juli 2018 
Hasil analisis regresi secara simultan

ANOVA $^{\text {b }}$

\begin{tabular}{|lr|r|r|r|r|r|}
\hline Model & Sum of Squares & Df & Mean Square & F & Sig. \\
\hline 1 & Regression & 561.611 & 3 & 187.204 & 50.113 & $.000^{\mathrm{a}}$ \\
& & 403.452 & 108 & 3.736 & & \\
& & & & & \\
& & & & & & \\
& Residual & 965.063 & 111 & & & \\
\end{tabular}

a. Predictors: (Constant), Disiplin Kerja, Gaya Kepemimpinan, Motivasi

b. Dependent Variable: Kinerja Karyawan

Sumber: Data primer yang diolah, 2017

Pengujian pengaruh variabel bebas secara bersama-sama terhadap variabel terikatnya dilakukan dengan menggunakan uji F. Hasil perhitungan statistik menunjukkan nilai $\mathrm{F}$ hitung $=50,113$. Dengan menggunakan batas signifikansi 0,05, maka diperoleh nilai signifikansi tersebut lebih kecil dari 0,05. Hal ini berarti bahwa hipotesis yang menyatakan bahwa secara simultan variabel gaya kepemimpinan, motivasi dan disiplin kerja mempunyai pengaruh terhadap kinerja karyawan.

\subsection{Koefisien Determinasi $\left(R^{2}\right)$}

Koefisien determinasi merupakan besaran yang menunjukkan besarnya variasi variabel dependen yang dapat dijelaskan oleh variable independennya. Dengan kata lain, koefisien determinasi ini digunakan untuk mengukur seberapa jauh variabel- variabel bebas dalam menerangkan variabel terikatnya. Nilai koefisien determinasi ditentukan dengan nilai adjusted $R$ square sebagaimana dapat dilihat pada tabel 3 :

Tabel 3

Koefisien determinasi

\begin{tabular}{|r|r|r|r|r|}
\hline & & & $\begin{array}{c}\text { Adjusted R } \\
\text { Square }\end{array}$ & Std. Error of the \\
\hline 1 & $.763^{\mathrm{a}}$ & .582 & .570 & 1.933 \\
\hline
\end{tabular}

a. Predictors: (Constant), Disiplin Kerja, Gaya Kepemimpinan, Motivasi Sumber: Data primer yang diolah, 2017

Jurnal Komunikasi Bisnis dan Manajemen Vol.5 No.2 Juli 2018 
Hasil perhitungan regresi dapat diketahui bahwa koefisien determinasi (adjusted $R^{2}$ ) yang diperoleh sebesar 0,57. Hal ini berarti 57\% variasi variabel kinerja karyawan dapat dijelaskan oleh variabel gaya kepemimpinan, motivasi dan disiplin kerja, sedangkan sisanya sebesar $43 \%$ diterangkan oleh variabel lain yang tidak diajukan dalam penelitian ini.

\subsection{Uji t ( Uji Hipotesis Secara Parsial )}

Hipotesis dalam penelitian ini diuji kebenarannya dengan menggunakan uji parsial. Pengujian dilakukan dengan melihat taraf signifikansi ( $p$ - value), jika taraf signifikansi yang dihasilkan dari perhitungan di bawah 0,05 maka hipotesis diterima, sebaliknya jika taraf signifikansi hasil hitung lebih besar dari 0,05 maka hipotesis ditolak.

Tabel 4

Hasil Uji t Secara Parsial

\begin{tabular}{|c|c|c|}
\hline Variabel Bebas & t hitung & Sig. t \\
\hline Gaya Kepemimpinan (X1) & 3.784 & 0.000 \\
\hline Motivasi (X2) & 3.628 & 0.000 \\
\hline Disiplin Kerja (X3) & 2.665 & 0.009 \\
\hline
\end{tabular}

Sumber: output SPSS diolah, 2017

\subsubsection{Uji Hipotesis 1 ( H1 )}

Dari table 4 terlihat bahwa hasil pengujian hipotesis gaya kepemimpinan menunjukkan nilai thitung sebesar 3,784 dengan taraf signifikansi 0,000. Taraf signifikansi tersebut lebih kecil dari 0,05, yang berarti bahwa hipotesis dalam penelitian ini menolak Ho dan menerima Ha. Dengan demikian dapat berarti bahwa hipotesis H1 " Gaya Kepemimpinan mempunyai pengaruh positif terhadap Kinerja karyawan " diterima.

\subsubsection{Uji Hipotesis 2 ( $\mathrm{H} 2$ )}

Dari tabel 4.12 terlihat bahwa hasil pengujian hipotesis motivasi 
menunjukkan nilai thitung sebesar 3,628 dengan taraf signifikansi 0,000. Taraf signifikansi hasil sebesar 0,000 tersebut lebih kecil dari 0,05, yang berarti bahwa hipotesis dalam penelitian ini menerima Ha dan menolak Ho. Dengan demikian dapat berarti bahwa hipotesis H2 " Motivasi berpengaruh positif terhadap Kinerja karyawan “ diterima.

\subsubsection{Uji Hipotesis 3 ( H3 )}

Dari tabel 11 terlihat bahwa hasil pengujian hipotesis disiplin kerja menunjukkan nilai t hitung sebesar 2,665 dengan taraf signifikansi 0,009. Taraf signifikansi hitung sebesar 0,009 tersebut lebih kecil dari 0,05, yang berarti bahwa hipotesis dalam penelitian ini menolak Ho dan menerima Ha. Dengan demikian berarti bahwa hipotesis H3 " Disiplin kerja mempunyai pengaruh positif terhadap Kinerja karyawan “ diterima.

\section{KESIMPULAN}

1. Hasil pengujian hipotesis telah membuktikan terdapat pengaruh antara motivasi dengan kinerja karyawan. Pengujian membuktikan bahwa motivasi memiliki pengaruh positif terhadap kinerja karyawan. Dilihat dari perhitungan yang telah dilakukan diperoleh nilai koefisien sebesar 0,343 dan nilai thitung sebesar 3,628 dengan taraf signifikansi hasil sebesar 0,000 tersebut lebih kecil dari 0,05, yang berarti bahwa hipotesis dalam penelitian ini menerima Ha dan menolak Ho. Dengan kata lain kinerja mempunyai pengaruh terhadap motivasi pekerja.

2. Hasil pengujian hipotesis telah membuktikan terdapat pengaruh antara gaya kepemimpinan dengan kinerja karyawan. Pengujian membuktikan bahwa gaya Kepemimpinan memiliki pengaruh positif terhadap kinerja karyawan. Dilihat dari perhitungan yang telah dilakukan diperoleh nilai koefisien sebesar 0,316 dan nilai $t$ hitung sebesar 3,784 dengan nilai 
signifikansi sebesar 0,000 tersebut lebih kecil dari 0,05 dengan demikian Ha diterima dan Ho ditolak. Dengan kata lain Gaya Kepemimpinan pada dasarnya menekankan untuk menghargai tujuan individu sehingga nantinya para individu akan memiliki keyakinan bahwa kinerja aktual akan melampaui harapan kinerja mereka.

3. Hasil pengujian hipotesis telah membuktikan terdapat pengaruh antara disiplin kerja dengan kinerja karyawan. Pengujian membuktikan bahwa disiplin kerja memiliki pengaruh positif terhadap kinerja karyawan. Dilihat dari perhitungan yang telah dilakukan diperoleh nilai koefisien sebesar 0,222 dan nilai $\mathrm{t}$ hitung 2,665 dengan taraf signifikansi hitung sebesar 0,009 tersebut lebih kecil dari 0,05, yang berarti bahwa hipotesis dalam penelitian ini menolak Ho dan menerima Ha. Dengan kata lain disiplin kerja karyawan bagian dari faktor kinerja.

4. Motrivasi memiliki pengaruh yang paling dominan terhadap kinerja karyawan Lion Group Perwakilan Kalimantan.

\section{DAFTAR PUSTAKA}

Ferdinand, Augusty. 2006. Metode Penelitian Manajemen. Edisi 2. BP Universitas Diponegoro, Semarang.

Ghozali, Imam. 2005. Aplikasi Analisis Multivariate dengan Program SPSS. Semarang: BP Universitas Diponegoro. Semarang.

Handoko, T. Hani. 2003. Manajemen Edisi 2. BPFE. Yogyakarta.

Hasibuan, Malayu. 2004. Manajemen Sumber Daya Manusia. PT Bumi Aksara. Jakarta.

Robbins, Stephen. P. 2006. Perilaku organisasi. Edisi Bahasa Indonesia. PT Indeks Kelompok GRAMEDIA. Jakarta.

Rivai, Veithzal dan Basri. 2005. Performance Appraisal: Sistem Yang Tepat Untuk Menilai Kinerja Karyawan Dan Meningkatkan Daya Saing Perusahaan. PT RAJAGRAFINDO PERSADA. Jakarta.

Sekaran, Uma. 2006. Research Methode For Business: Metodologi Penelitian Untuk bisnis. Salemba Empat. Jakarta.

Jurnal Komunikasi Bisnis dan Manajemen

Vol.5 No.2 Juli 2018 
Siagian, Sondong. P. 2002. Kiat Meningkatkan Produktivitas Kerja. PT Rineka Cipta. Jakarta.

Simamora, Henry. 1997. Manajemen Sumber Daya Manusia. STIE YKPN. Yogyakarta.

Supranto, J. 2001. Statistik: Teori dan Aplikasi. Edisi keenam. Erlangga. Jakarta.

Tika, P. 2006. Budaya Organisasi Dan Peningkatan Kinerja Perusahaan. PT Bumi Aksara. Jakarta. 